\title{
Factors Affecting the Application of Preparation of Financial Statements at UMKM in South Tangerang
}

\author{
RINNY MEIDIYUSTIANI, INDAH RAHAYU LESTARI
}

\begin{abstract}
This study aims to determine the factors that affect the application of the preparation of financial statements. Where the factors studied are the knowledge of accounting, understanding of accounting, level of education and work experience / business of MSME owners. The population of this research is restaurant and café in South Tangerang. Sampling convience sampling. The number of samples from the study was 60 respondents. From the results of the analysis shows that, accounting knowledge and accounting comprehension have a positive effect on the application of the preparation of financial statements. While the variables level of education, and work experience / effort does not affect the application of the preparation of financial statements.
\end{abstract}

\section{Preliminary}

UMKM stands for Micro, Small and Medium Enterprises. UMKM is one of the important parts of the economy of a country and region, as well as the state of Indonesia UMKM is very important role in the speed of the community economy. MSMEs are also very helpful for the state / government in terms of creating new jobs and through SMEs also created many units of new work units that use new workers that can support household income. In addition, MSMEs also have high flexibility when compared with larger-capacity businesses. At this time SMEs need special attention and supported by accurate information, so that there is a directional business links between small and medium business actors with elements of business competitiveness, namely the market network. There are two aspects that must be developed to build the market network, these aspects [1-4].

In carrying out business activities are often the manager of SMEs find it difficult in recording what happened to the business operations [5-6]. The difficulties concern the activities and assessment of the results achieved by each business. Especially if we have to do measurement and assessment on activity that happened in business activity or non effort [7]. Often in the scale of small and medium enterprises business results are said to

Revised Manuscript Received on July 05, 2019

Rinny Meidiyustiani,

Fakultas Ekonomi dan Bisnis Universitas Budi, Luhur,

meidiyustiani@gmail.com be good if the income is now higher than the previous income. Whereas the success indicator is not only measured from the income alone, it is necessary to measure and classify the transactions or activities that occur and pengikhtisaran these transactions. Without good record and report performance evaluation of UMKM is not easy to do [8-10].

SAK ETAP (Entity Without Public Accountability) is a new system applied to UMKM to optimize the performance of UMKM [11-13]. A new system will generally be considered complicated, complex, sophisticated, and so forth so that there is an element of avoidance or rejection by its users. Implementation of accounting standards is expected to provide a picture of the performance of MSMEs in the past and the future. [14$18]$

Implementation of accounting bookkeeping to produce financial statements is still difficult for MSMEs. Limitations of accounting bookkeeping knowledge, the complexity of the accounting process, and the assumption that financial statements are not important for MSMEs. Implementation of accounting on SMEs is influenced by the turnover of the company because the higher the turnover of the company means the more complex financial management that must be done by the company [19-21]. Therefore, companies need the help of a system that can facilitate the management of corporate finance, hence the company implements accounting [22].

The financial statements are information about the economic activity and the condition of the company resulting from an accounting information system [23]. This report is typically used by banks or investors as a basis for analyzing creditworthiness applying. Therefore financial statements are important for MSMEs and Start Ups [24-26]. If financial statements need to be made if you want to grow with an injection of funds from them [27-28].

\section{Theoretical Review}

\subsection{Definitions and components of financial statements}

Understanding financial statements according to the Indonesian Institute of Accountants as set forth in the Financial Accounting Standard No. 1 (IAI, 2017: $3)$, is a structured presentation of the financial position and financial Published By:

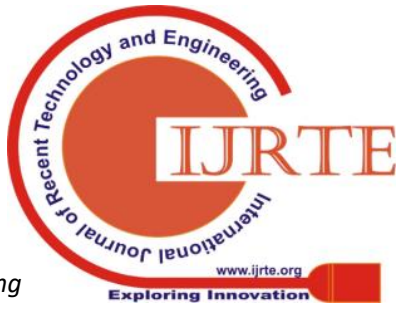


performance of an entity. The purpose of the financial statements is to provide information on the financial position, financial performance, and cash flows of entities beneficial to most users of the report in economic decision-making. The financial statements also show the results of management accountability for the use of the resources entrusted to them. In order to achieve these objectives, the financial statements present information on the entity which includes: assets, liabilities, equity, income and expenses including gains and losses, contributions from and distribution to owners in their capacity as owners and cash flows.

\subsection{Knowledge Accounting}

Accounting knowledge also has a big hand in the progress of managed businesses. Accounting knowledge owned by small and medium business owners will provide many benefits in the use of accounting information. Low accounting knowledge will lead to undertakings of business failure management so it is very difficult for business actors in determining what policies will be taken.

\subsection{Understanding of Accounting}

Understanding according to the Indonesian General Dictionary has a clever understanding and understanding, while understanding is the process, how to understand or understand. This means that it can be concluded that people who have an understanding of accounting is a clever and understand about accounting. Someone said to understand the accounting is understand and clever how the accounting process was done until it becomes a financial statement with guiding principles and standards preparation of financial statements that are based on SAK ETAP.

\subsection{Level of Education}

Definition and Definition of Education based on RI's Law. 20 Year 2003 on National Education System. Education is a conscious and well-planned effort to create an atmosphere of learning and learning process so that learners actively develop their potential to have spiritual spiritual strength, self-control, personality, intelligence, noble character and skills needed of him, society and nation.

\subsection{Business Experience}

Experience is a capital that will continue to grow as long as a person becomes an employee or run a business. Experience can be gained from all the actions of a person in the past and or can be learned, because by learning from the past one can gain experience.

Staw (1991) argues that experience in doing business is the best predictor of success, especially when the new business is related to previous business experience. The need for experience in processing the business is increasingly needed with increasing environmental complexity. There is strong evidence that entrepreneurs have parents who work independently or entrepreneurialbased. This kind of parental awareness and flexibility is

inherent in her children since childhood. It is this selfnature that then encourages them to set up their own business. Although there is no comparative study with an entrepreneur whose parents are not entrepreneurs, a relationship with an entrepreneur appears to be an important aspect that shapes a person's desire to become an entrepreneur

\subsection{Research Hypothesis}

H1: Knowledge Accounting affects the application of Financial Statements to MSMEs

$\mathrm{H} 2$ : Accounting Understanding Influential Significant to the Application of Financial Statements to MSMEs

H3: Educational Level Affects the Implementation of Financial Statements to MSMEs

H4: Business Experience Affects the Application of Financial Statements to MSMEs

\section{Research Methods}

\subsection{Population and Sample Research}

In accordance with certain sample characteristics required, ie MSMEs in South Tangerang, this technique is selected to ensure that only samples that have certain elements that have been determined by the researchers to be taken as samples. If the sample is selected to facilitate the retrieval of data, it can also be called convenience sampling (Sugiyono, 2015: 85). The sample is part of the population used to infer or describe the population. The sample in this research is food and beverage entrepreneur or a kind of Café or Restaurant in South Tangerang as many as 60 SMEs

\subsection{Variable Operationalization}

The following is the Variable Operational Table from the research:

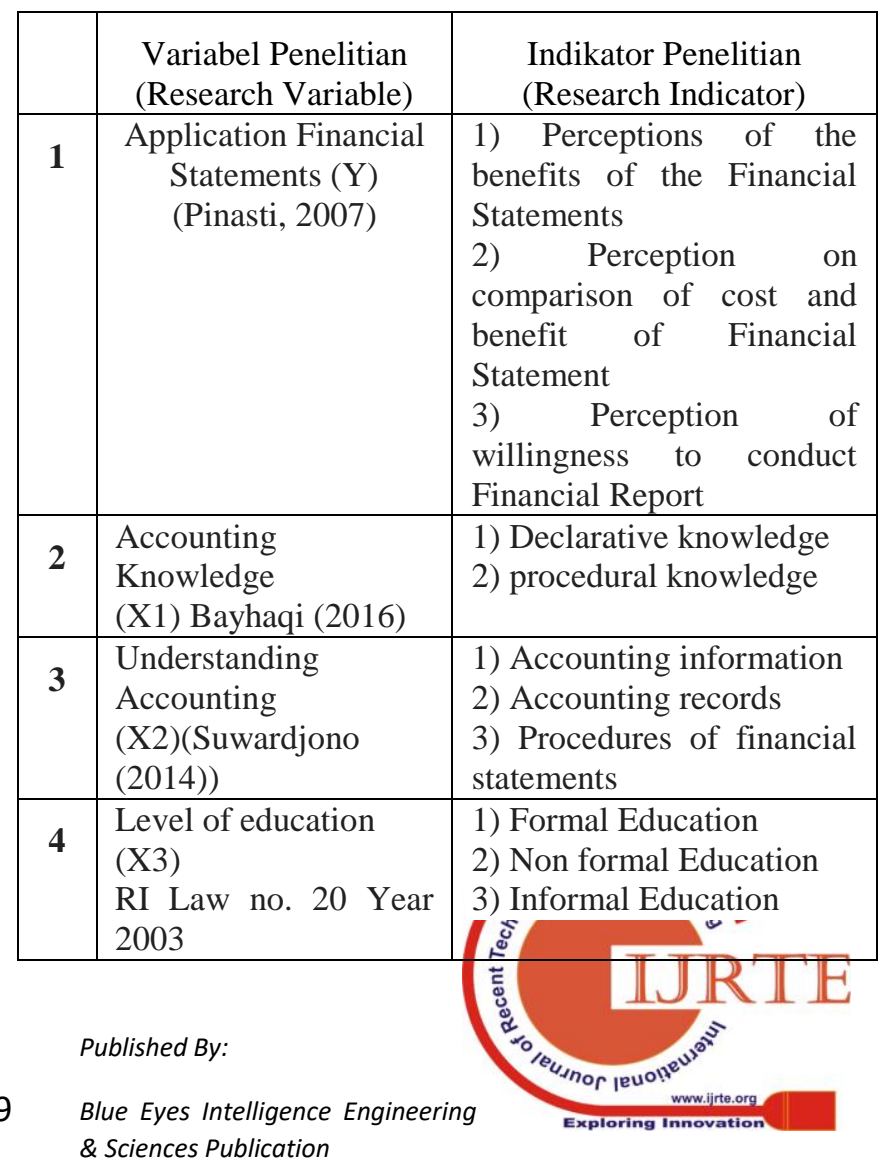


5

\begin{tabular}{l|l} 
Business Experience & 1) Work Experience \\
(X4) & 2) Pattern educate of the \\
Staw (1991) & parents \\
Rofi (2012) &
\end{tabular}

Table 1: Variable Operational Table

\subsection{Data Analysis}

Researchers used the PLS method to analyze this multivariate model. The model consists of four exogenous latent variables, namely accounting knowledge, accounting comprehension, owner education, owner experience and application of financial statements. The model proposed by the researcher is analyzed using Smart PLS 3.2.1 application. The model design is shown as follows:

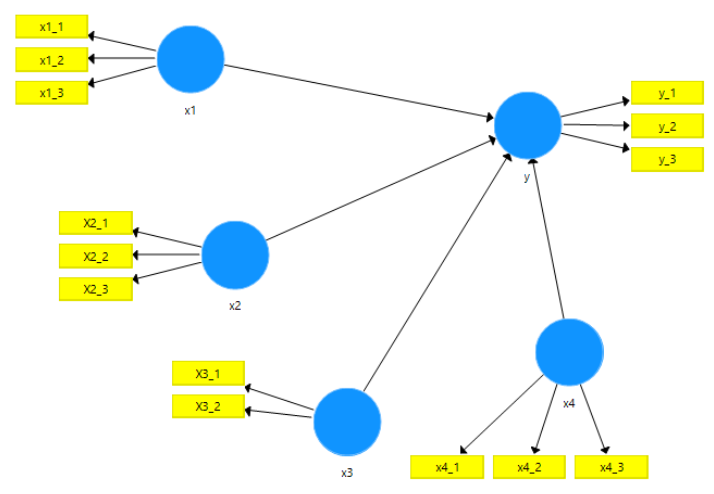

Figure 1: Model Design

\subsection{Discussion}

The result of tabulation of questionnaires that have been inputted using Microsoft Excel software is exported into Smart PLS 3.2.1 application to be further analyzed. The data used is complete data. Out of a total of 60 respondents. This 60 respondents data is used for measurement model and structural model analysis.

The measurement model for validity and reliability test, coefficient of determination model and path coefficient for model equation, can be seen in the picture below:

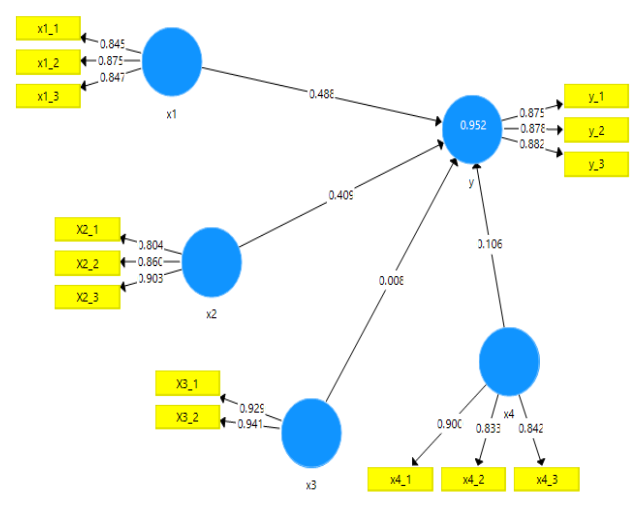

Figure 2: Measurement Model

\subsection{Result Display Picture of PLS Algorithm}

Based on the above loading factor results it can be concluded that the construct has good valid vergent validity.

\subsubsection{Realibility Test}

Data outer loading shows some indicators that have values above 0.70 so the results are considered to meet the standards and do not need iteration.

If traditional research uses Cronbach's alpha value as a reference, then in PLS- use different sizes to determine reliability. Composite reliability values are used instead (Bagozzi \& Yi, 1988). Hair (2014) requires that the composite reliability value should be above 0.70 or 0.60 if the study is exploratory

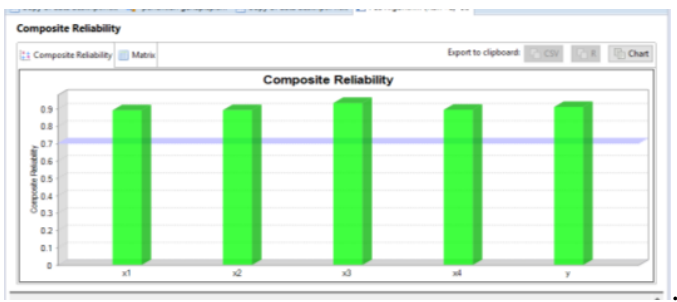

Figure 3: Composite Reliability

The table above shows that all latent variables have composite reliability values above 0.60 . The test results state that the model can meet the reliability test. The following figure describes the visual output of the composite reliability results of the SmartPLS 3.2.1 application. So it can be concluded that the construct has good reliability

\subsubsection{Validity test}

This test checks for convergent validity by requiring the Average Variance Extracted (AVE) value of each latent variable to be above the 0.50 threshold.

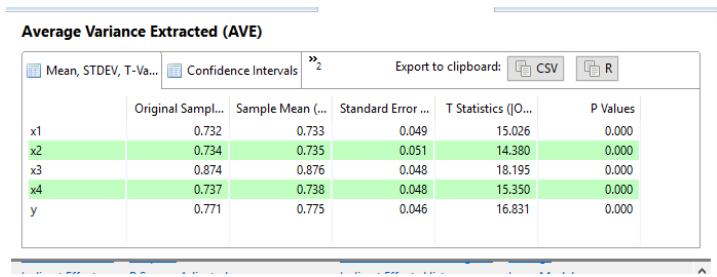

Figure 4: Average Variance Extracted (AVE)

The table above shows that all latent variables have an AVE value above 0.50 . So it can be concluded that the construct has good validity.

The structural model in the PLS is evaluated by using R2 For the dependent variable and the path coefficient value for the independent variable which then assessed its significance based on the statistics of each path.

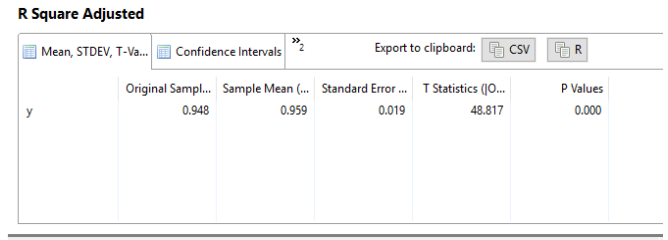

Figure 5: R Square Adjusted

This explains that the contribution of all

Published By: 
exogenous latent variables to endogenous variables is $94,8,2 \%$ while the rest of $5,2,8 \%$ is caused by variable or other factors outside this research model.

The structural model of this research can be seen in the following figure:

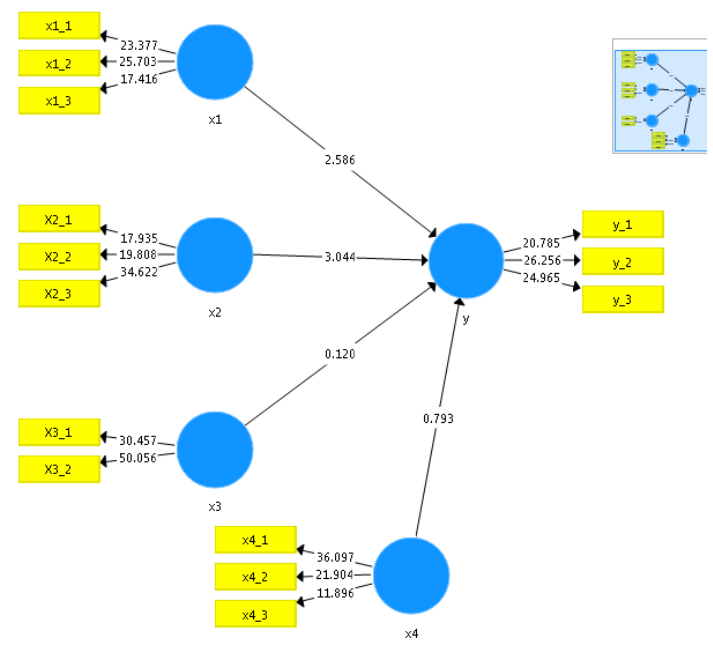

Figure 6: Structural Model

\subsection{Hypothesis testing}

To assess the significance of the prediction model in testing the structural model, it can be seen from the tstatistic value between the independent variables to the dependent variable in the Path Coefficient table in the Smart PLS Output below:

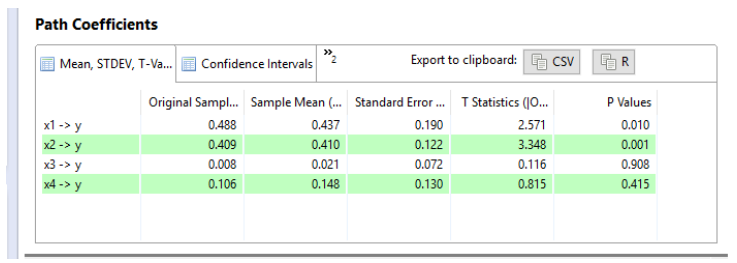

Figure 7: Research Model Coefficients

$\mathrm{T}$ (2-tailed) test results with a 5\% significance level as shown in the Table above shows that:

\subsubsection{Testing the first hypothesis}

From the table above can be seen the original sample estimate LS is 0.488 with significance below $5 \%$ indicated by the value of $\mathrm{t}$ statistics 2,571 bigger than $\mathrm{t}$-table value of 2,0017. The original value of sample estimate positively indicates that knowledge of owner accounting has a positive effect on the application of financial statements. Based on the results of the regression can be concluded that the first hypothesis accepted.

\subsubsection{Testing the second hypothesis.}

From the table above can be seen the original sample estimate LS is 0.106 with significance below $5 \%$ indicated by the value of $t$ statistics of 3.348 is greater than the ttable value of 2.0017 . The original value of sample estimate positively indicates that the owner's accounting understanding has a positive effect on the application of financial statements. Based on the results of the regression can be concluded that the second hypothesis accepted.

\subsubsection{Testing the third hypothesis}

From the table above can be seen the original sample estimated LS is 0.008 with significance above $5 \%$ indicated by the value of $\mathrm{t}$ statistics 0.116 smaller than the t-table value of 2.0017. The original value of sample estimate positively indicates that the owner's accounting education has no positive effect on the application of financial statements. Based on the results of the regression can be concluded that the third hypothesis is rejected.

\subsubsection{Testing the fourth hypothesis}

From the table above can be seen the original sample estimated LS is 0.008 with significance above $5 \%$ indicated by the value of $\mathrm{t}$ statistics 0.815 smaller than the t-table value of 2.0017. The original value of sample estimate positively indicates that the owner's accounting education has no positive effect on the application of financial statements. Based on the results of the regression can be concluded that the fourth hypothesis is rejected.

\section{Conclusions and Recommendations}

Based on the results of this study, the following conclusions are obtained:

1. Variable Accounting knowledge positively affects the application of the preparation of financial statements.

2. Variable Accounting comprehension has a positive effect on the application of financial report preparation.

3. Variable level of education does not affect the application of the preparation of financial statements.

4. Variable business experience / work has no effect on the application of the preparation of financial statements.

Suggestions With the limitations of this study, the following are suggestions for further research:

1. Further research is expected to increase the variation of representative representation of respondents SMEs restaurants and cafes spread in South Tangerang, so more able to reflect the population.

2. Future research is expected to increase the number of samples, so as to improve the generalization level of research results.

3. Future research designing the questionnaire to be done better, so that the information obtained more complete so as to capture the phenomenon to be studied.

4. Future research needs to complement the existence of qualitative research by doing in depth interview to restaurant and café owners so that it is better able to capture the phenomenon of the problem with more depth, so that the research result can be more useful in the Published By:

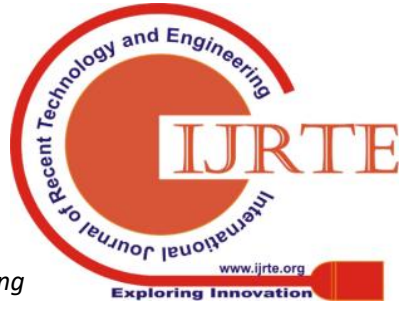


development of restaurant and café business in the future come.

Ethical clearance - Not required

Source of funding- Self

\section{Conflict of Interest - Nil}

\section{References}

[1] Abdulkadir Muhammad dan Rilda Murniati. Segi Hukum Lembaga Keuangan dan Pembiayaan. Bandung: Citra Aditya Bakti, 2000.

[2] Belkaoui, Ahmed Riahi. Teori Akuntansi, Edisi 5 Buku 1. Terj. Ali Akbar Yulianto dan Rismawati Dermauli. Jakarta: Salemba Empat, 2006.

[3] Darmawan. Metode Penelitian Kuantitatif. Bandung: Remadja Rosdakarya, 2013.

[4] E. Kieso, Donald, Jerry, J Weygandt and Teery D. Warfield. Accounting Principles, Edisi 12. Jakarta: Salemba Empat, 2007.

[5] E. Kieso, Donald, dkk. Akuntansi Intermediate, Edisi 12, Jilid 1. Jakarta: Erlangga, 2008.

[6] Hair Jr, et al. Essential of Business Research Method USA, 2014.

[7] Harahap. Analisis Krisis Atas laporan Keuangan, Edisi Pertama Cetakan Ketiga. Jakarta: Raja Grafindo Persada, 2007.

[8] Hoetomo. Kamus Lengkap Bahasa Indonesia. Jakarta: Mitra Pelajar, 2005.

[9] Ikatan Akuntansi Indonesia. Standar Akuntansi keuangan. Dewan Standar Akuntansi Ikatan Akuntansi Indonesia, Jakarta, 2017.

[10] Keraf, Gorys. Diksi dan Gaya Bahasa. Jakarta: Gramedia Pustaka Utama, 2001.

[11] Muljono, Teguh Pudjo, Drs, Akuntan. Analisis Laporan Keuangan Untuk Perbankan. Jakarta: Djambatan, 1990

[12] Poerwadarminta. Kamus Umum Bahasa Indonesia. Jakarta: Balai Pustaka, 2006.

[13] Poespoprodjo. Pengantar Dialektika dan Ilmu. Bandung: Remadja karya, 1987.

[14] Rudianto. Pengantar Akuntansi Adaptasi IFRS. Jakarta: Erlangga, 2012.

[15] Santoso, Singgih. Statistika Induktif Edisi 5. Yogyakarta: BPFE, 2012.

[16] Sugiyono. Metode Penelitian Pendidikan (Pendekatan Kuantitatif dan Kulaitatif dan R\&D). Bandung: Alfabeta, 2015.

[17] Suwardjono. Teori Akuntansi: Pengungkapandan Sarana Interpretatif. Edisi Ketiga BPFE, Yogyakarta, 2010.

[18] Suwardjono. Pengantar Akuntansi. Edisi Ketiga BPFE, Yogyakarta,2014.

[19] Anggraini, Gama Risti. Kamaludin dan Sri Adji Prabawa. Pengaruh dan Faktor-Faktor Internal dan Eksternal Perbankan Terhadap Stratergi Pemberian Kredit Sebagai Upaya dalam Meminimalkan Nilai NPL. Jurnal Ilmiah Manajemen Vol. 15. No 5, 2013.

[20] Divianto Febrianty. Pengaruh Pemahaman Pelaku UMKM dalam Menyusun Laporan Keuangan terhadap Implementasi Laporan Keuangan Berdasarkan SAK ETAP dengan Persepsi Pelaku UMKM sebagai Moderating Variabel. International of Journal of Social Science and Business Vol 1(3) pp. 166-167, 2017.

[21] Irwan Nurkholis. Tingkat Pendidikan, Skala Usaha, Pengalaman Usaha, dan Masa Jabatan Berpengaruh terhadap Penerapan Laporan Informasi Akuntansi Pada Usaha Kecil dan Menengah. Universitas Dian Nuswantoro Semarang, 2014.
[22] Kurniawansyah. Penerapan Pencatatan Akuntansi dan Penyusunan Laporan Keuangan Berdasarkan SAK ETAP pada UMKM Desa Gembongsari Kecamatan Puro Kabupaten Banyuwangi, 2016.

[23] Mulyani, Sri. 2014. Faktor-Faktor yang Mempengaruhi Kualitas Laporan Keuangan pada UMKM di Kabupaten Kudus, Vol 11 No.2, Oktober 2014.

[24] Nanang Shon Hadji, dkk. Penerapan Penyusunan Laporan Keuangan pada UKM Berdasarkan SAK EMKM di Surabaya, Universitas Islam Madura, 2017.

[25] Putra, H. A., dan Kurniawati, E. P. Penyusunan Laporan Keuangan untuk Usaha Kecil dan Menengah (UKM) Berbasi Standar Akuntansi Keuangan Entitas Tanpa Akuntabilitas Publik (SAK ETAP). Jurnal Pekan Ilmiah Dosen FEB (halaman. 547-580) Salatiga: Universitas Kristen Satya Wacana: Fakultas Ekonomika dan Bisnis, 2012

[26] Rahmawati dan Puspasari. Implementasi SAK ETAP dan Kualitas Laporan Keuangan UMKM Terkait Akses Modal Perbankan, 2017.

[27] Satyo. UKM dan Kebutuhan Standard, Media Akuntansi, 4 (XII), 4, 2005 .

[28] Suhartati Titi, Warsini Sabar, Implementasi Standard Akuntansi Entitas Tanpa Akuntabilitas Publik (SAK-ETAP) dalam Proses Akuntansi dan Penyusunan Laporan Keu-angan Pada Usaha Mikro, Kecil dan Menengah (UMKM). Jurnal Akuntansi, Keuangan dan Perbankan, 2014 